\title{
The God School: informal Christian education and emerging aspirations among de facto stateless children living in Cambodia
}

\begin{abstract}
Statelessness research to date has mainly focused on legal analyses and the plight of adults who are seen to have little 'navigational capacity'. Children are often regarded simply as those caught up in the complicated lives of their parents or guardians. Very rarely are the voices of stateless children heard, still less are their aspirations documented. This paper foregrounds children's experiences and argues that despite appearing to be 'stuck' in a position of liminality, de facto stateless children have much to teach us about the differing roads to aspiration. An analysis of the everyday lived realities of Cambodia's stateless children reveals how religious identity, specifically through Christian conversion, becomes central to how their aspirations are socially produced, and how these aspirations come to assist them in navigating ethnic and institutional exclusion.
\end{abstract}

Keywords: Cambodia; Aspirations; Children, Statelessness, Education, Christianity

\section{Introduction}

Article 1 of the 1954 Statelessness Convention defines a stateless person as one 'who is not considered a national by any State under the operation of its law.' This is legally defined as de jure stateless. The term de facto stateless exists to describe the situation of a large range of people whose lived experiences are effectively of statelessness, but who do not satisfy the de jure definition (Malischewski, 2013). This article examines the important but understudied subject of aspirations among de facto stateless children. These children, like other ethnic Vietnamese living in Cambodia, may have legitimate claim to Cambodian or Vietnamese 
nationality but currently do not have access to legal protections from either country and are prevented from doing so due to the interplay of exclusionary institutional and economic factors (Canzutti 2019).

Studies of stateless communities in Asia have brought attention to the existing gaps in nationality laws that perpetuate the condition of statelessness, and highlight the ethno-racial discriminative treatment stateless populations receive. Examples include the Rohingya in Myanmar (Lewa 2009), the Biharis in Bangladesh (Fahmida Farzana 2008; Redclift 2011, 2013a), Indonesian and Filipino refugees and migrants in Malaysia (Allerton 2014, 2017a) and the Bajau Laut in Malaysia (Acciaioli, Brunt, and Clifton 2017). Despite increased attention to how statelessness is experienced by adults (Redclift 2013, Sigona 2016), there remains a need for a thorough and interdisciplinary understanding on how children experience statelessness. Ball et al. (2014) argue that an obvious oversight in tackling child statelessness is an evidence-based understanding of decision-making by children, their family members, kinship networks, community leaders, middle-men and women regarding birth registration. I would go further and suggest that ethnographic examples are needed to move beyond an analysis of what children lack and draw attention to the lived realities of statelessness. Allerton's work (2014) on the lives of the children of migrants in Sabah, East Malaysia adds a much needed nuance to the study of statelessness; I build on this by exploring how children's aspirations emerge and their implications.

Literature on children's aspirations usually focus on locations where children are expected to be: in school. In this context, children's aspirations are largely framed around their future occupation prospects (Chambers et al. 2018). Research outside the classroom has focused on street children's aspirations that, like children in school contexts, has led to a discussion 
about their desired futures and the impacts of NGO intervention (Biggeri, Ballet, and Comim 2011; Merriman and Guerin 2007).

Stateless children live in a context of legal liminality (Menjivar 2006), out of the reach of development frameworks and key institutions reproducing 'doxic' aspirations (Zipin et al. 2015), . They are excluded from the trajectories of aspiration laid out in the Sustainable Development Goals or the World Development Report (World Bank 2015) that focus exclusively on citizens, therefore little is known about their aspirations. This not only leaves a gap in the literature on aspirations, but also restricts our understanding of the conditions that enable new possibilities for aspiration among children in informal contexts. My contribution is to underscore the role of religion as a key dimension for thinking about the production of aspiration among ethnic Vietnamese de facto stateless children living in Cambodia.

This paper contains four sections. The first section introduces the ethnographic context of this research, briefly detailing the historical backdrop that frames the ethnic hostility that ethnic Vietnamese children experience. Moreover, we see how a period of post-war reconstruction in Cambodia opened a door for assistance from NGOs, and Christian mission. Secondly, the methodology used for this study will be outlined, emphasising the benefits of using visual research methods and participant observation in order to understand aspirations in their different forms.

The third section draws on literature that discusses aspiration in the context of migration and religion to show how religion is influential in generating aspirations which are distinct to those driven by economic betterment. This scholarship, whilst not addressing statelessness directly, provides a helpful point of entry by highlighting how religious communities provide a relational context in which identity, hope and agency can thrive. Of significance is the temporal dimension religion brings to aspirations, as something to create a sense of being in 
the present and action in the future. Fourthly, drawing on the case study of the 'God School', I demonstrate how children process their exclusion and, through Christian conversion, begin to view and (re)present themselves as 'good' to subvert negative stereotypes concerning the ethnic Vietnamese in Cambodia, to be accepted in the present. In addition, I will demonstrate how children's appropriation of Christian practice such as prayer gives children a 'voice' which may not necessarily be heard by political leaders or development planners, but which can impact upon their home and community.

\section{Ethnographic context}

Cambodia is home to many ethnic and indigenous groups, the largest of these groups being ethnic Vietnamese (Schliesinger 2015). The historical portrayals of the Vietnamese as 'immoral', 'untrustworthy' and 'illegal' (Edwards, 1996; 2007; Goscha, 2012) frame how they are perceived in Cambodia today. This rhetoric can be traced back to the French colonial period onwards where successive regimes have painted the Vietnamese as leeches, colonialists and the enemy of the Cambodian Kingdom (Amer 1994, 2006, 2013). It has been described as Cambodia's anti-Vietnamese obsession (Frewer 2016).

Cambodia's tumultuous, war-stricken history has resulted in what Banerjee and Duflo (2011) call 'institutional inertia'. The economy is growing rapidly with weak institutions that undermine human rights, education and strong legal systems (Hill and Menon 2013). After the time of the Khmer Rouge (1975-1979) many international NGOs came to Cambodia intending to assist its people and help rebuild a country in ruins (Brinkley 2011), bringing mixed results. Included in the list of 'helpers' were Christian missionaries (Choi-Fitzpatrick 2014). The God School is one of many evangelical Christian NGOs that I encountered in Cambodia, but significantly, it focuses on serving excluded Vietnamese populations. In a context of weak institutions, unaccountable practices and an inconsistent administration of 
citizenship regimes, factors such as ethnicity and poverty can override the legal distribution of such documents (Ang and Chan 2014, Ehrentraut 2013, Berman 1996). Ethnic Vietnamese communities in Cambodia have a patchwork of official documentation. For children, their parents' lack of success of securing relevant documents and the lack of a birth certificate is what makes them at risk of statelessness (Sperfeldt 2017). Thus, populations that engage with missionary activity, like the Vietnamese communities in this study, have social needs which are largely neglected by the government, in the context of privatised (and poorly managed) social insurance, healthcare and education systems.

The God School was started by Linh Anh, an ethnic Vietnamese Christian, and was staffed by Christian missionaries who worked as teachers from Vietnam, USA, and the Philippines. Visiting supporters of the mission came to serve as volunteers from Europe and Korea, providing technical assistance to missionary teachers, and sometimes offered English language learning summer camps at the end of the school term. Nearly 100 students at the God School, aged from 3 to 17, were divided into three sections: kindergarten, middle school and upper school. Missionary teachers delivered Vietnamese, English and Mathematics lessons, in Vietnamese language, to all children in middle and upper school, with each child engaging in at least three lessons a day (Rumsby 2015). Participant's parents, who mostly practiced Confucianism and Mahayana Buddhism, consented to children receiving a Christian education before enrolling them at the school.

The God School was located in Preah Thnov, a village made up of predominately long-term residents of mixed-marriage Khmer and Vietnamese and ethnic Vietnamese households. Similar to Parsons and Lawreniuk's (2018) study, which evidenced local authorities categorising Khmer people living in predominately Vietnamese communities in Phnom Penh 
as 'Vietnamese', mixed-marriage households in this study were also regarded by local authorities as Vietnamese. Khmer spouses without documents could not prove their Khmer identity, so were categorised as Vietnamese and lived as though effectively stateless. Two children referenced in this paper were from mixed marriage households, but I also refer to them as ethnic Vietnamese, given this is the identity that shaped their legal status. Some houses were on land, spread out over two floors with an open space at the front for children to play, whilst others were built on the shoreline with floating boat houses decorating the Tonlé Sap River.

\section{Methods}

I began my research in the community of Preah Thnov in 2012. The data presented in this article derives from ethnographic research undertaken in Cambodia from October 2015 - July 2016. In the penultimate section I briefly draw on fieldwork conducted in 2019. Research focused on issues concerning education, faith identity, belonging and aspirations among the community. I conducted 144 semi-structured interviews with 37 children aged between 6-17 years old - 13 boys and 24 girls. I defined a child as anyone under the age of 18, as per the Convention on the Rights of the Child (CRC). Interviews were only one part of the research; I also carried out participant observation, built relationships with interviewees and other participants/community members by spending time with them, eating meals and having informal conversations about daily life. I gained access to the group of research participants through voluntarily teaching at the God School. The ethnography was primarily conducted in the school setting because going to school was a part of the participants' everyday routine (Christensen 2004). In addition, I was able to get to know and interview nine caregivers/parents out of the 37 interviewed children, who consented to be part of the 
research. I also interviewed 6 teachers who were long-term missionaries at the school, as well as observing the running of the mission closely.

I entered the research with a commitment to taking children's agency and voice seriously (author 2017). Consequently, children were involved in research design and practice where possible. During a scoping study, they told me what themes, topics and experiences they wanted to explore through focus groups (see figure 1). After these discussions, I grouped their suggestions into four broad themes as avenues of research enquiry. I also discussed with children what kind of methods they wanted to use, sharing ideas based on other research that had been carried out with children across the world (Bagnoli and Clark, 2010; Moskal, 2010; O'Kane, 2008). It was agreed that visual research methods (VRM) were preferred and drawings could be used to enhance conversations during interviews.

\section{Figure 1 Themes suggested by children for exploration during the research}

VRM such as drawings in the form of past and future timelines, self-portraits (Bagnoli 2009), identity flowers (Rumsby 2019) and participant observation are particularly well suited to understanding children's aspirations. The selected activities offered a temporal analysis of children's lives, shedding light on how participants see themselves in the present, what significant events have shaped their past and how they imagine their future. Such an approach is imperative to understanding the multi-dimensional nature of aspirations (Hart 2016) by including information on histories, power dynamics, and how values and cultures have been shaped and affected. Combining participant observation with VRM, we can see how 'emergent' behaviours that are alternative to the dominant social arrangements are created (Zipin et al., 2015, p. 238).

The objectives of this research were discussed at length with the gatekeeper and principal of 
the God School, and with participants prior to the research. Verbal informed consent was sought from all participants and caregivers. Children decided to choose their own pseudonyms, and some took the opportunity to adopt Western names.

\section{Religion producing present and future aspirations}

The study of aspirations has been applied to migrants and developed in more detail by Carling $(2002 ; 2014)$ who considered how migrants aspired to 'the good life', that is better jobs, education, living conditions for their family members, healthcare and so on. A generally accepted definition sees aspiration as something orientated towards the future, driven by "wants, preference, choices, calculation" (Appadurai 2004:7). This 'capacity to aspire' is dependent on the capability to achieve economic development, with poor people having less 'navigational capacity' than the rich who are better connected and have already a stock of capital needed for wealth and success. Aspirational theory is grounded in the model of the 'good life', something characterised by economic betterment which migrants have been noted to strive for (Carling and Collins, 2018; Baig, 2015).

Religion has been utilised to re-affirm migrant identity, particularly in reproducing traditional values and culture to the second generation. Kurien's (1999) study of three Hindu Indian religio-cultural organizations in USA, for instance, shows the significance of the bala vihar (child development) meetings in promoting Indian culture, morality and philosophy among South Indian Hindu immigrants. In addition, Korean and Chinese churches in America have been shown to teach traditional values that resonate with Christian tradition as well as reinforcing age-based hierarchies (Chong 1998; Yang 1999). Whilst religion can reproduce ethnic traditions, it can also challenge and transform them. Chen's (2006) study of Taiwanese Immigrant Christians and Buddhists in Southern California demonstrates how conversion to 
evangelical Christianity democratises relationships between children and parents, shifts the moral vocabulary of the family from filial piety to religious piety and celebrates the autonomy of children. These studies emphasise the reproduction of family values as a key part of collective aspirations.

Considering the influence religion has on individual and collective aspirations reveals that aspirations are not restricted to the material, nor are they necessarily future-orientated. Khan (2012) demonstrates that 'becoming' does not equate to economic progress or material well-being; rather, social and religious aspirations are about the ways that Muslims in Pakistan can become better practitioners of Islam, usually through theological discourse, dialogue and argumentation.

Furthermore, religion has also generated aspirations interpreted as an act of living in the present. Noman Baig (2015), in his study of 'aspiration as breathing' subjectivity in Pakistan, notes:

unless one makes a conscious effort to be in the present, the past and the future are the dwelling places of a subjectivity stretched between experiences and potentialities, the weight of which, regardless of their nature, clogs the ability to truly aspire or breathe and be in the present (Baig 2015:353).

Baig's (2015) ethnographic work looks at the Sufi Islam meditative practice of $z i k r$, and how it impacts on the life of a money merchant. Baig shows how the daily practice $z i k r$ reconfigured the life of Aamir (the ethnography's main interlocutor) from a businessperson into a medium of God's 'blessing'. Being able to aspire or breathe in the present, Baig 
argues, promoted rest and resistance in the tumultuous context of capitalism and religious extremism in Pakistan.

Aspirations matter then because they come to signify what has come to have meaning and value for individuals and social groups in the present and the future. They provide navigational pathways and reference points, yet a narrow definition of aspiration as economic development says little about the socio-political - or religious - conditions that shape and influence them (Hart 2016).

This paper shines analytical light on how ethnic Vietnamese children aspired to be known as 'good', and sought to challenge negative stereotypes that circulated about the Vietnamese in Khmer society. Being good is just as much an aspiration for the present as it is in the future. Through the example of Compassion Day, a day of collective servitude and collective endeavour at the God School, children are actively seeking to (re)present themselves in a context of hostility and exclusion, to create a more peaceful present. In addition, an analysis of children's practice of Christian prayer shows aspiration as more than individual cognitive actions, like dreaming or hoping, but a pretext towards future action. The next sections will illustrate these arguments with ethnographic examples.

\section{Children of the God School}

The bustling sounds of motorbikes, cockerels and children's conversation were amplified through the narrow street where the school is located. At 6:30am students in their uniforms would sit gathered around a food stall slurping noodles. Outside the school, children talked and ordered each other around excitedly as they played games, skipping over a rope that is lifted higher and higher to increase the difficulty with every successful jump. These were 
scenes I witnessed daily. A passer-by without an understanding of the political context of the Vietnamese community in Cambodia might interpret these children to be 'normal' rather than an 'impossible' or unsolvable problem (Allerton 2017b). One difference between these children and other children who passed them by on foot and push-bike is the uniform. Whilst the Khmer uniform is a distinct white shirt and navy-blue skirt / trousers, the God School's attire is bright blue embossed with the school's logo and tagline.

Despite the uncertain status of children at the God School, some children were able to complete the first few grades in Khmer school without papers. This access was contingent on paying bribes. However, after grade 7 (12 years old) admissions became stricter and children could not continue their Khmer education without a birth certificate. Children's experiences of Khmer School, if they went, was marred by unfair treatment from peers and teachers believed to be rooted in racism.

For example, Lucy attended what she called 'Khmer school' (Cambodian public school) until grade 6 before leaving. When I asked why she left she explained:

I studied until grade 6 because they separate high school and lower school. Grade 7 is high school, so I could not go to school because I had no paperwork to show I was Cambodian. I was born here [Cambodia], my parents are from here. I cannot get papers because the face tells you who you are - Vietnamese or Khmer. The name too.

During a self-portrait exercise young people could produce a creative output to explain their feelings of their life in Cambodia, Lucy drew the following:

\section{Figure 2 Lucy's wants}


The Vietnamese-language text in the drawing translates as the following:

\section{WANT:}

The children here don't have papers, which means that they cannot study and are shouted at by many people, just when walking to a neighbour's house; they are insulted and do not dare reply, but can you imagine how it feels? [sad emoticon] I only know that I am a child who really wants papers, so I can go to different places, and work for the LORD. I also want to study and be able to travel and not be afraid of anyone, and have the freedom to do many things and then my dream will become reality. [happy emoticon]

These fearful sentiments related to their statelessness were echoed by Tiffany, aged 14 years old. Tiffany explained:

We own neither house nor land, just on houseboats, painstakingly searching for each penny in order to worry about every next family meal. Without papers in Cambodia, the Khmer don't welcome us, they force us to return to Vietnam. But without papers the people in Vietnam also don't welcome us. Now my life does not know where to return to, with no homeland and no country. If we cannot study, then our futures will be dark and gloomy. I am afraid and worried, not knowing what I shall do or where I will go in the future. Every day I live in this fear. Please have mercy on me, a child in Cambodia (Tiffany, girl, aged 14).

Lucy and Tiffany's insights reference the impact of not studying for their futures. Lucy expresses a desire for freedom of movement, and both girls mention the impact being Vietnamese without formal papers has on the opportunity of access. This awareness points to the limitations of their aspirations from a doxic perspective. They cannot be included on the 
premise that they are not seen to be Cambodian citizens, and their ethnic identity and citizenship status fuels such rejection.

The God School became a domain where the children's Vietnamese heritage was unproblematic. Patrick, aged 14, explained how speaking Vietnamese at the God School made him feel accepted: 2being at the God School feels different. I feel they [other students] are different from the other friends because they do not separate me and ask me if I am Khmer, they accept me." Sara, aged 11, echoed a similar sentiment: "when I came to the God School, I feel happy because all my friends play with me like brother and sister. I also like speaking Vietnamese outside". Children all noted the negative consequences of speaking Vietnamese in public. Most notable was being called 'Youn', a derogatory Khmer slur for Vietnamese people (Oesterheld 2014).

Problematically, these children cannot learn the Vietnamese language in mainstream school, but are not welcome in state schools long enough to learn the Cambodian language. Therefore, whilst they would surely benefit from a Cambodian education for integration purposes, which they aspire to, they have little choice but to attend the God School or roam the streets. Moreover, the experience of the God School resonates with the aspirations of the local Vietnamese community. Children at home are socialised in collective modes of being which translate into aspirations, for instance, the collective endeavour to be good, and to provide for their family.

\section{Aspiring to be 'good'}

In this section, I draw attention to a child's socialisation experience and the role of the family in instilling a moral code in their children, rooted in Vietnamese philosophies, and how 
children embraced the Christian teaching at the God School as a way to fulfil the collective aspiration to be 'good'.

The family is generally seen as crucial in instilling the sense/level of 'morality' of its members (Tuong 1991). Good moral citizens are those who abstain from so-called 'social evils' (tệ nạn xã hội) that are thought to degenerate high Vietnamese moral standards. Such citizens do not, for instance, gamble, neither are they addicted to alcohol or drugs (Marr 1981). For the children in this study, practicing 'Vietnamese-ness' children applied to kinship ties, Vietnamese culture, and its symbolic resources. Children have observed, and attempted to adopt Vietnamese views on filial duty, Buddhist and Neo-Confucian practices as taught by their parents. Children collectively aspired to embody these values to please their parents, yet during the research period, they explained their discontent over their own community's failure to uphold these values.

The discussion about morality was a frequent topic of conversation during the research period. Young people were acutely aware of, and troubled by, the lack of appropriate moral behaviour around them. Despite the community's apparent disapproval of gambling and excessive drinking, it was rife among both the Khmer and Vietnamese residents. This discontent is exemplified in a conversation with one of the students. I asked her what things are important to them in life she explained, "my dream is I want to be a soldier in the army." "Why?" I asked, "I want to go to the ones who gamble and catch them, there are two or three groups either side of my house." This response illustrates the aspiration to reorder the perceived lack of morality in the community. Furthermore, when young people explained their reasons for practising Christianity, they would talk about how despite being formally Buddhist they themselves would often behave in immoral ways, leading to frustration. Children wanted to fulfil their parents' wishes to be 'moral people' but declared that they 
would themselves gamble, swear and fight. Just as we saw with Lucy and Tiffany's excerpts earlier that children experienced status frustration, children also experienced dissatisfaction about the inconsistency between the moral ideals of the community (and themselves) and the extent to which these ideals were practiced.

Interestingly, whilst parents' aspirations for their children had a different rationale, the aspirations generated by studying at the God School converged with that of parents. Both placed emphasis on 'being good', but the God School offered something new to children. As 'emplaced' subjects, that is, those "whose daily lives become infected with new cultural, temporal and material encounters due to the mobilities of others" (Robertson and Ho 2016:2266), children were introduced to new ritual forms, new sets of ideals, and new possibilities for sociality (Austin-Boos 2003), all of which gave children new possibilities for aspiration.

Helle Rydstrøm's (2003) ethnography on growing up in Northern Vietnam highlights how, along with the family, the education system is crucial for the production of children's 'good morality'. The God School teachers stated that one of their purposes was to teach young people what is right and what is wrong, from a biblical perspective. The variant of Christian morality that the teachers propagated fitted quite closely to dominant notions of goodness in traditional Vietnamese society. Whilst there are elements of Protestant Christian teaching which are incompatible with Vietnamese tradition, for instance the prohibition of ancestor worship, other prominent markers of collective aspirations - for instance, filial duty, living a moral life free from alcoholism and gambling - took a new form as God's laws and were adopted by students. 
Young people who appropriated Christianity would often talk of a newfound motivation to abstain from social evils. They often contrasted their experience of Christian conversion and consequential behaviour change with their former Buddhist backgrounds. Conversion, in the context of this paper, denotes a process of change that involves the (re)definition of self and other in accordance, or discordance, with a religious schema (Woods 2012). Conversion is itself a discursive construct that adopts different forms and meanings over space and time, so children's experiences of faith are likely to change over time. Nevertheless, I take as primary evidence for conversion a child's articulation of changing religion or beliefs. I want to suggest that children are not merely passive subjects of Christian indoctrination but have actively appropriated - that is taken for their own use - Christian practices in their daily lives, outside of the God School. Thus, they have (in some cases) converted from local Buddhist practices to evangelical Protestant Christianity.

Conversion involved an internalisation of a new belief system, which can be observed as a new religious identity, or a change from one religious' identity to another. For example, Emma told me:

Before I was a Christian and followed Buddha, I would gamble, play cards, and gamble on sports, anything that entailed the exchange of money. I would win money too, because I used to cheat. I do not do that anymore (Emma, girl, aged 14).

In this example, Emma is presenting a narrative around religious conversion as a change in who she is both in terms of religion and of behaviour. Not all children converted to Christianity and students would often have conversations amongst themselves about the nature of and consequences of conversion: 
I started believing in God when I went to this [the God] school and some of my friends who believe in God told me that God loves us and makes us happy. I do not know the differences between God and Buddha, some friends say God and Buddha are wife and husband and they have separated that is why some people believe in God and some Buddha. What is different is they [friends] say whoever believes in Buddha will go to the heaven but whoever believes in God will go to hell. Yet, I want to go to this [the God] school; I want to believe in God because I am a child of God. Some of my friends they do not like to go to this [God] school because they say to believe in God is bad. They hate God (Hien, girl, 13 years old).

Whilst not all children converted, a majority of students expressed a strong association with the God School as part of their Vietnamese-Christian identity. During a flower petal exercise, participants wrote being Christian as part of their identity in addition to being good, truthful, and Vietnamese.

\section{Figure 3 Quoc, boy aged 14, Identity flower}

Going to a Christian school permanently staffed by Vietnamese missionaries, and attended by others with a Vietnamese background, gave participants a confidence to 'be Vietnamese' and a desire to collectively witness their good behaviour to their communities for recognition. This is exemplified on 'Compassion Day', which took place twice during fieldwork. The idea of the day is for students to go out into the community and 'serve'. Litter is rife in the area, therefore as an act of servitude and collective endeavour young people take to the streets and pick up rubbish as well as praying for the villages. When I asked about their motivation for such an endeavour, children said it was so "other people, both Vietnamese and Khmer, would think they were good". During Compassion Day, children openly talked and prayed in Vietnamese as they went around the villages collecting rubbish. They all wore their God 
School uniforms - a significant identity marker - which reads "Vietnamese mission in Cambodia" in English on the back. Participants regularly associated the wearing of the uniform as symbolic not only of their pupillage at the school but also their identity as a Christian. Patrick aged 14 told me "this uniform is the school of God and the one who believes in God is wearing this T-Shirt." This was a common answer I received from children explaining why they drew themselves in their uniforms in their self-portrait.

\section{Figure 4 Children collecting rubbish Compassion Day}

Compassion Day was met with resistance at first. After the first Compassion Day participating children told me how they were ridiculed on the street. Khmer and Vietnamese villagers, incidentally the village where the school is located, shouted things like "If you were a Christian you wouldn't just pick up the trash one day, you'd do it every day", or "Why are you a Christian, your parents are Buddhist?" However, on the second Compassion Day, which came around six months later, people from the same village, said: "oh you children are so good". This acknowledgement of the group being 'good' is also indicative of their Vietnamese-Christian identity. Children had their aspirations to be known for being good affirmed when they appropriated and performed their Christianity, which takes a strongly habituated moral form in public.

The example of Compassion Day reveals how a new environment and a new discursive narrative of goodness became embroiled with local aspirations, which then was performed and accepted in its modified form. This is not the only example of how religious practice became central to generating aspirations. The next section will focus on children's practice of Christian prayer and how that gives them confidence to voice their desires for change in their communities. 


\section{The Capacity to Aspire: voice and new modes of enactment}

In the capacity to aspire, Appadurai (2004) treats voice as a cultural capacity and not just a generalised and universal democratic virtue. New social movements, driven by the poor themselves, show how mobilisation can expand and enrich the capacity to aspire within a specific social and cultural milieu. Appadurai offers an example of the 'capacity to aspire' in the ethnographical account of The National Slum Dweller's Foundation: a powerful grassroots organisation that formed an international Alliance united in their concerns for gaining secure land tenure, secure urban infrastructure and durable housing (Appadurai 2004:71). This example illustrates how a disempowered community was able to gain political legitimacy by taking locally acquired knowledge and displaying it before powerful players. Yet, the work of the Alliance and the political voice of the slum dweller could not have been achieved without the political backing and networks it had. Appadurai (2004), who writes of this example in a book funded by the World Bank, is a member of the Alliance himself. Without his political brokerage, it seems unrealistic for many disadvantaged groups to achieve the conditions he sets out - that the poor must acquire a 'voice' which engages in social, political, and economic issues in terms of ideologies, doctrines, and norms, which are extensively communal and credible. In reality, most aspirational projects of the poor will be much smaller in scale and may not follow a linear trajectory towards future global development or a politics of recognition, but can nevertheless achieve something still have a profound impact, as shown in the example of the children's activities on Compassion Day.

The case study of the children of the God School suggests that preceding the 'capacity to aspire' is a process of cultural destabilisation or transformation that reimagines a world beyond the social-structural limits. Ethnographic observations reveal how the God School, as a transnational and religious nexus, became a new site of contestation and belonging as 
children engaged in new religious practices with members of a global Christian network. Pierre Hadot suggests that "spiritual exercises" develop "a complete reversal of our usual way of looking at things" (1995, p. 83) and this is the case as demonstrated by children's exposure to the Christian practice of prayer. From the visits of international English-teachers and missionaries to the school, children were able to learn of world affairs and see beyond their own geography. Ideas around good governance were exposed to the children as volunteers and visitors openly discussed situations of life at home or war or political discord in their own country. I observed children articulating prayers which were intersubjective, local, global and dialogical in nature. For instance, through the practice of prayer, children acted out their belonging to a Christian community by identifying with others' experiences of the world and responding with 'activist-like' behaviour, voicing their political desires using prayer.

As outsiders in Cambodia, ethnic Vietnamese children who live on the margins largely lack global interconnectivity. However, in this context they were given opportunities to interact with transnational others who reciprocated an affinity with them as Christians. Prayer was a communal activity. At the end of each section of the day, i.e. before lunch and before the school end, teachers and students gathered and prayed through thematic topics and oftenspontaneous prayers were offered. Through daily prayer, children prayed for themselves, each other's needs, their country and families. Building a daily dialogue with a God who they believed listened to them appeared to give children freedom and confidence to speak.

Sitting in circles, sometimes holding hands other times standing up, children would pray aloud for others to hear their intersession. On one occasion at the end of school day, a 12year-old boy led the other children in praying for the Vietnamese and Cambodian governments: that they would not be politically corrupt, that they would pursue justice and 
their people would be protected. Another girl who had heard from an international visitor about the political upheaval in Ukraine prayed for the conflict with Russia to end and peace to exist between the two nations. Children's convictions were legitimised by listeners who through the collective use of the Hebrew word 'amen', meaning 'so be it', created an intersubjective union, and arguably allowed a moment where children could subvert their uncertain status and belong to an alternative citizenry - 'citizens of heaven' - where their speech was meaningful and efficacious.

Whilst voicing their political desires, children were developing a consciousness that could potentially translate into political action to challenge their own marginality and status. This is further suggested a conversation I had with Olivia, 13. I was genuinely moved as this gentle, unassuming and graceful girl told me with tears in her eyes how she wished she could make [citizen] 'papers' for children who do not have them:

For the children who have no papers the Khmer will send them back to Vietnam. I do not think this is fair because they were born here but they push them back to Vietnam that is not fair. I am still young compared to the Khmer so I do not know a solution to the problem, but if their [the children's] parents allow me to lead them to make the papers, I will lead them, if my grandma allows me to. If they have the paper, the Khmer will not send them back to Vietnam. When I grow up I want to be the servant of God, the one to do the papers for the children, make the papers for the children and like the teachers here to teach them. I feel really sad because some children they do not have papers, so they may go back to Vietnam and I cannot help them, and I am sad about that. When I serve God and help the children, I will feel happy. (Olivia, girl, aged 13). 
Olivia's sense of justice and desire to act to seek fairness is conceptualised as a service to God. She had considered the plight of paperless Vietnamese children and wishes to act.

The way children displayed confidence to speak about their beliefs outside of the school further revealed how prayer is being used as a tool to challenge disharmony and declare a desire for a change in circumstances. They disrupted the existing order of things and articulated a vision of a new order, often with tangible outcomes. For example, when the team of teachers visited the surrounding village to speak to parents about their child's progression in school, one parent was evidently anxious and restless about personal circumstances. In a dramatic reversal of traditional hierarchical power structures, the child offered to pray for her mother, who agreed. The child prayed for her mother to have peace, wisdom, help and protection, showing how children had new influences in the domestic realm and at times were able to disrupt practices foundational to habituated norms.

As children interacted with missionary teachers and the supporters who visited the God School, they created a tapestry of ideas about the world and their place in it. Moreover, whilst providing children with informal, unaccredited learning, the God School became a significant space for community building where children seek to become teachers themselves, offering a valuable service for others in their communities. I often found when discussing children's futures during their timeline exercises some would note how they too wanted to continue their education at the God School and then go on to teach there. Sreya aged nine explained to me

I have been thinking I want to be a teacher since I was 7 years old. I thought about it from then because at that time, I got sick and all my teachers [from another English school] went to Vietnam so no one taught me. I want to teach my sister, who is 3 
years old, and many other children to know how to read and write. I want to teach the children in this village, because I want to help the children in this village to know how to read and write Vietnamese, Cambodian is difficult for them. (Sreya, girl, aged 9)

Of course, just because the aspirations to teach are articulated, the question remains regarding the 'viable futures' (Zipin et al. 2015:227) of children who attend informal education. Criticism has been directed at the individualistic discourse of 'raising aspirations' that increase rather than weaken obstacles by operating ideologically to simplify the structural constraints and mask the severities of historically grounded inequalities (Zipin et al. 2015). Yet, it is primarily the Cambodian government's failure to formally implement agendas like the CRC (to which it is a signatory) that has cut children off from educational opportunities. In the absence of state-sponsored support, local, informal and unrecognised frameworks like the God School have partially provided the means of legitimacy and recognition of the Vietnamese communities with whom they conduct their work. As Rachel Burr (2006) argues, it would be a mistake to assume that only internationally driven agendas change lives.

When I returned to the village in 2019, some of these children's aspirations were being realised. Sreya was still a student at the school but several young people who used to be students during the research period were now paid teachers at the school. In addition, the school has started offering job-training pathways for graduates in tailoring, IT, paper art and teaching training. This is not to argue that organisations like the God School can or should become a replacement or alternative to rights: states have responsibilities and obligations to legally protect children. However, by making a distinction between education as an official human rights mechanism and the God School, as an informal space where education can be accessed, the complexities of navigating opportunities - especially for the stateless - are revealed. 
Given the focus on aspirations, a critical reflection on the God School as an NGO operating in Cambodia has not been fully possible. Yet, given the crucial work recently published on the commodification of children for volunteer tourism in Cambodia, one must ask is the God School another "hug-an-orphan" organisation? (Guiney 2018). Given space limitations, two things are worth mentioning. First, no project existed whereby the school accepted paid for voluntary placements as a way to make money and children were not asked to perform stereotypes of vulnerability and emotion for economic value. Second, families of children were engaged in their children's education. They attended parent and teacher meetings and tracked their child's learning. The God School then, could be labelled a community-based organisation given teachers lived in the villages they served, and the community was actively involved.

\section{Conclusion}

Presenting a case of how aspirations are socially produced in a context of a Christian mission school forces us to consider the many roads to aspirations, and how they emerge in a context of poverty, disadvantage and rapid change. If aspirations are formed in interaction within communities and in the 'thick of social life' (Appadurai 2004:67) then they should be expected to be found anywhere, even among communities that are seemingly invisible, beyond the reach of the state and thus the 'development' project (McMichael 2004). Children often inherit the aspirations dictated by their parents and the environmental conditions that limit or make those aspirations possible. For stateless children living on the margins of society there appears to be little if any navigational capacity within formal structures. However, taking a closer look we see that new forms of being do emerge, including in the most unlikely of contexts. 
Aspirations outside of the doxic logic are hard to measure as they represent the intangible. As the example of Compassion Day shows, the feeling of being 'good' is of great importance to communities of children who want to (re)represent themselves to the broader community. We must then, seek to understand how aspiration as 'feelings' come to motivate communities to aspire present and future change. In this case, the salience of ethnic discrimination of the ethnic Vietnamese in Cambodia propels children to want to be 'good', alongside the collective aspiration of the family. Paying attention to these seemingly insignificant occurrences force us to stop and think about the intersubjective nature of aspirations, and the role of religious practice in partly attaining them. School, for instance, is about much more than education in its measurable form. It is a place of exchange. The God School provided outside possibilities, enabling children to connect with a globalised community of Christians. This transnational connection offered opportunities for children to acquire a voice, which they used to speak out how their reality could be different - the first step in aspiring for an alternative future.

\section{Notes}

1. For a detailed discussion on the legal limbo of the ethnic Vietnamese in Cambodia see Nguyen and Sperfeldt (2012) and Ang and Chan (2014).

2. Some data in the section Children of the God School was presented in (author 2015) and (author 2017); permission has been granted to re-use the material.

Conflict of Interest Statement. On behalf of all authors, the corresponding author states that there is no conflict of interest. 


\section{Figures}

\begin{tabular}{|l|l|l|l|}
\hline \multicolumn{1}{|c|}{ Time and } & Relationships & God & Morality \\
\hline Play with friends & Friends & Believe in God & Say no bad words \\
\hline Games & Family & Want to tell others & No fighting \\
\hline Work & & about God & \\
\hline Study & & & Good testimony of \\
\hline Future & & & \\
\hline Films & & & \\
\hline Care & & & \\
\hline & & & \\
\hline
\end{tabular}

Figure 1 Themes suggested by children for exploration during the research 


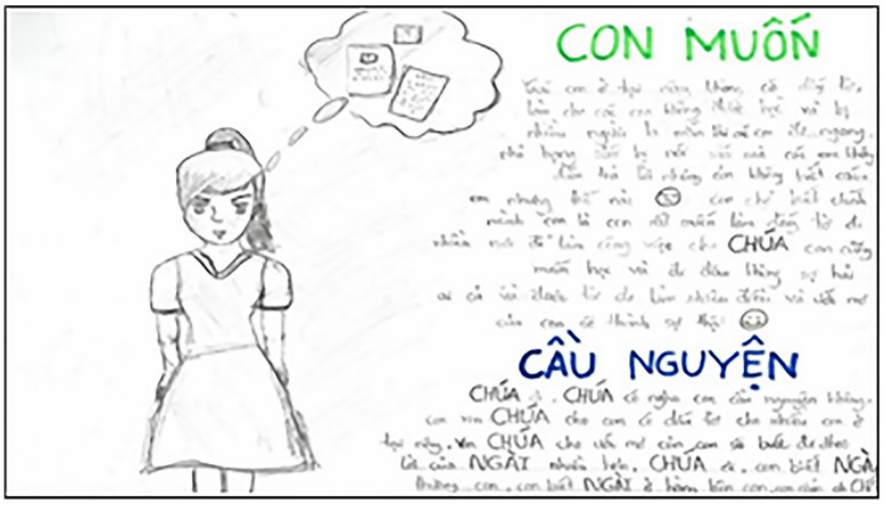

Figure 2 Lucy's wants

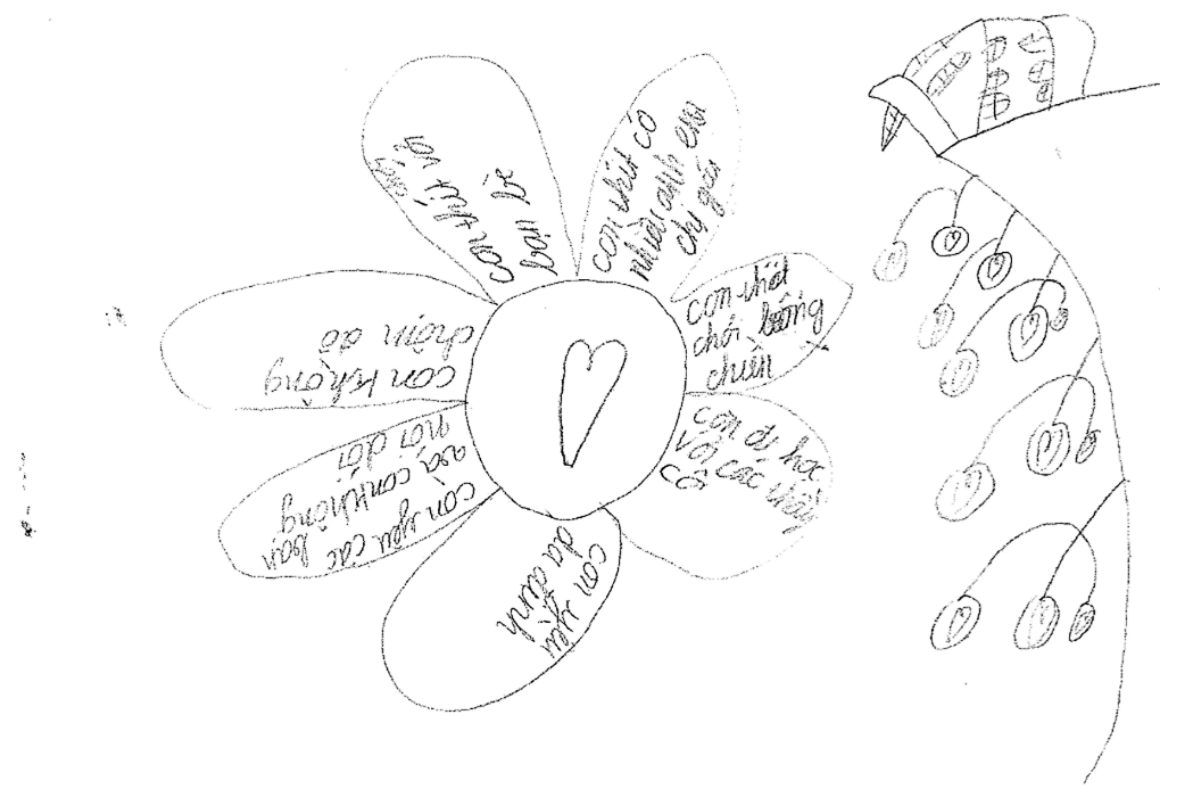

Figure 3 Quoc, boy aged 14, Identity flower 


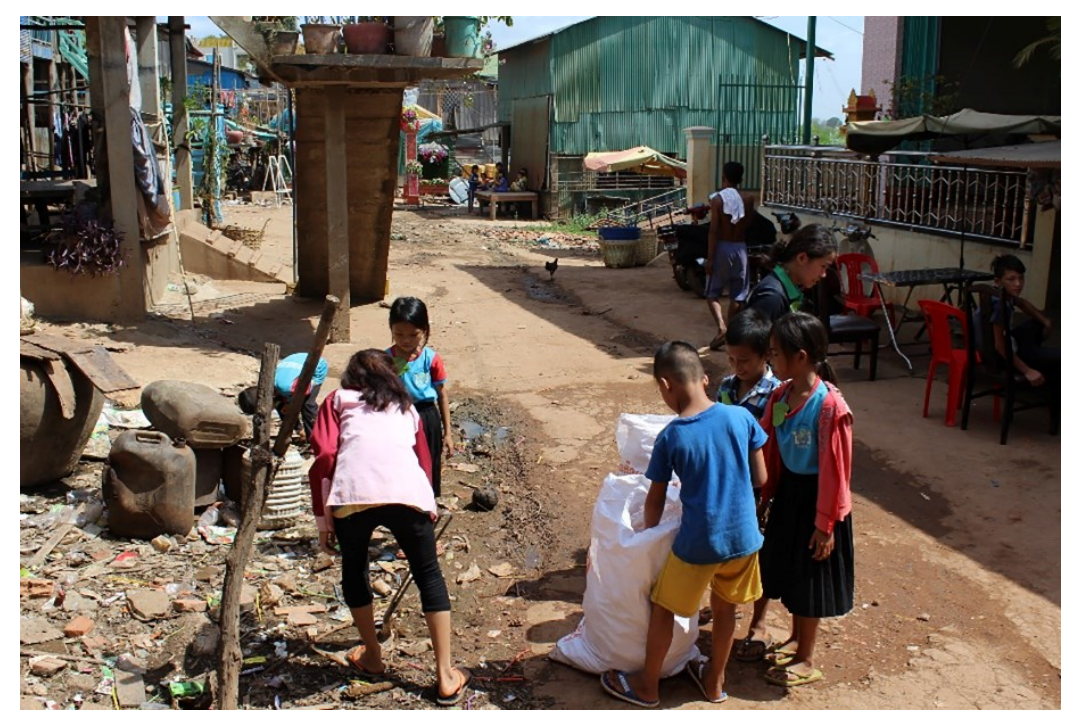

\section{Figure 4 Children collecting rubbish Compassion Day}

\section{References}

Acciaioli, Greg, Helen Brunt, and Julian Clifton. 2017. "Foreigners Everywhere, Nationals

Nowhere: Exclusion, Irregularity, and Invisibility of Stateless Bajau Laut in Eastern

Sabah, Malaysia.” Journal of Immigrant \& Refugee Studies 15(3):232-49.

Allerton, Catherine. 2014. "Statelessness and the Lives of the Children of Migrants in Sabah, East Malaysia.” Tilburg Law Review 19(1-2):26-35.

Allerton, Catherine. 2017a. "Contested Statelessness in Sabah, Malaysia: Irregularity and the Politics of Recognition.” Journal of Immigrant and Refugee Studies 15(3):250-68.

Allerton, Catherine. 2017b. "Impossible Children: Illegality and Excluded Belonging among Children of Migrants in Sabah, East Malaysia." The Journal of Ethnic and Migration Studies 44(7):1081-97.

Amer, R. 1994. “A Minority in at Risk ?” Contemporary Southeast Asia 16(2):210-38.

Amer, R. 2006. “Cambodia's Ethnic Vietnamese: Minority Rights and Domestic Politics.” Asian Journal of Social Science 34(3):388-409.

Amer, R. 2013. "Domestic Political Change and Ethnic Minorities: A Case Study of the 
Ethnic Vietnamese in Cambodia.” Asia-Pacific Social Science Review 13(2):87-101.

Ang, B. and J. Chan. 2014. Limbo on Earth: An Investigative Report On the Current Living Conditions and Legal Status of Ethnic Vietnamese in Cambodia. Phnom Pehn.

Appadurai, A. 2004. "The Capacity to Aspire: Culture and the Terms of Recognition.” Pp.

59-84 in Culture and Public Action, edited by V. Rao and M. Walton. Palo Alto,

California: Stanford University Press.

Austin-Boos, Diane. 2003. "The Anthropology of Religious Conversion: An Introduction.”

Pp. 1-14 in The Anthropology of Religious Conversion, edited by Buckser and Glazier. Lanham, Maryland.

Bagnoli, Anna. 2009. "Beyond the Standard Interview: The Use of Graphic Elicitation and Arts-Based Methods." Qualitative Research 9(5):547-70.

Bagnoli, Anna and Andrew Clark. 2010. "Focus Groups with Young People: A Participatory Approach to Research Planning.” Journal of Youth Studies 13(1):101-19.

Baig, Noman. 2015. “ASPIRING IN KARACHI Breathing Life into the City of Death.” Pp. 351-66 in Handbook of Religion and the Asian City : Aspiration and Urbanization in the Twenty-First Century, edited by P. van der Veer. University of California Press.

Ball, J., H. Beazley, L. Butt, and N. Fox. 2014. Advancing Reserach on "Stateless Children" Family Decision Making and Birth Registration among Transnational Migrants in the Asia-Pacific Region. Victoria, BC.

Banerjee, A. and E. Duflo. 2011. Poor Economics: A Radical Rethinking of the Way to Fight Global Poverty. 18th ed. New York: Public Affairs .

Berman, Jennifer S. 1996. "No Place Like Home: Anti-Vietnamese Discrimination and Nationality in Cambodia." California Law Review 84(3):817-74.

Biggeri, Mario, Jerome Ballet, and Flavio Comim. 2011. Children and the Capability Approach. London: Palgrave Macmillan. 
Brinkley, Joel. 2011. Cambodia's Curse: The Modern History of a Troubled Land. New York: Public Affairs.

Burr, R. 2006. Vietnam's Children in a Changing World. New Brunswick, N.J.: Rutgers University Press.

Canzutti, Lucrezia. 2019. “(Co-)Producing Liminality: Cambodia and Vietnam’s ‘Shared Custody' of the Vietnamese Diaspora in Cambodia.” Political Geography 71:26-35.

Carling, J. 2002. “Migration in the Age of Involuntary Immobility: Theoretical Reflections and Cape Verdean Experiences.” Journal of Ethnic and Migration Studies 28(1):5-42.

Carling, Jørgen. 2014. “The Role of Aspirations in Migration.” Pp. 23-25 in Paper presented at Determinants of International Migration, International Migration Institute, University of Oxford.

Carling, Jørgen and Francis Collins. 2018. “Aspiration, Desire and Drivers of Migration.” Journal of Ethnic and Migration Studies.

Chambers, N., E. Kashefpakdel, J. Rehill, and C. Percy. 2018. Drawing the Future: Exploring the Career Aspirations of Primary School Children from around the World.

Chen, Carolyn. 2006. "From Filial Piety to Religious Piety: Evangelical Christianity Reconstructing Taiwanese Immigrant Families in the United States.” International Migration Review 40(3):573-602.

Choi-Fitzpatrick, Austin. 2014. "To Seek and Save the Lost: Human Trafficking and Salvation Schemas Among American Evangelicals." European Journal of Cultural and Political Sociology 1(2):119-40.

Chong, Kelly H. 1998. "What It Means to Be Christian: The Role of Religion in the Construction of Ethnic Identity and Boundary among Second-Generation Korean Americans." Sociology of Religion 59(3):259-86.

Christensen, P. 2004. “Children's Participation in Ethnographic Research: Issues of Power 
and Representation." Children and Society 18(2):165-76.

Edwards, P. 1996. "Imaging the Other in Cambodian Nationalist Discourse before and during the UNTAC Period.” Pp. 50-72 in Propaganda, Politics, and Violence in Cambodia. A Democratic Transition under United Nations Peace-Keeping, edited by S. Heder and J. Ledgerwood. Armonk, N.Y: M.E.Sharpe.

Edwards, Penny. 2007. Cambodge: The Cultivation of a Nation, 1860-1945. Honolulu: Univeristy Hawaii Press.

Ehrentraut, Stefan. 2011. "Perpetually Temporary: Citizenship and Ethnic Vietnamese in Cambodia." Ethnic and Racial Studies 34(5):779-98.

Ehrentraut, Stefan. 2013. "Challenging Khmer Citizenship: Minorities, the State, and the International Community in Cambodia.” PhD Thesis. University of Potsdam.

Fahmida Farzana, Kazi. 2008. “The Neglected Stateless Bihari Community in Bangladesh:

Victims of Political and Diplomatic Onslaught.” Journal of Humanities and Social Sciences 2(1):1-19.

Frewer, T. 2016. “Cambodia’s Anti-Vietnam Obsession: Anti- Vietnamese Sentiment Dominates Cambodia, Even among Otherwise Progressive NGOs and Political Groups.” The Diplomat., September.

Goscha, Christopher E. 2012. Going Indochinese: Contesting Concepts of Space and Place in French Indochina. Copenhagen: NIAS Press.

Guiney, Tess. 2018. “'Hug-an-Orphan Vacations': 'Love' and Emotion in Orphanage Tourism.” Geographical Journal 184(2):125-37.

Hadot, Pierre. n.d. Philosophy as a Way of Life: Spiritual Exercises from Socrates to Foucault. Oxford: Wiley-Blackwell.

Hart, Caroline Sarojini. 2016. "How Do Aspirations Matter?” Journal of Human Development and Capabilities 17(3):324-41. 
Hill, Hal and Jayant Menon. 2013. "Cambodia: Rapid Growth with Weak Institutions." Asian Economic Policy Review 8(1):46-65.

Khan, Naveeda. 2012. Muslim Becoming: Aspiration and Skepticism in Pakistan. Durham: Duke University Press.

Kurien, Prema. 1999. "Gendered Ethnicity: Creating a Hindu Indian Identity in the United States." American Behavioral Scientist 42(4):648-70.

Lewa, C. 2009. "North Arakan: An Open Prison for the Rohingya in Burma." Forced Migration Review (32):11-13.

Marr, David. 1981. Vietnamese Tradition on Trial 1920-45. Berkeley: University of California Press.

McMichael, P. (3rd edition). London: Sage. 2004. Development as Social Change: A Global Perspective. Third. London: Sage.

Menjivar, Cecilia. 2006. “Liminal Legality: Salvadoran and Guatemalan Immigrants’ Lives in the United States.” American Journal of Sociology 111(4):999-1037.

Merriman, Brian and Suzanne Guerin. 2007. "Exploring the Aspirations of Kolkatan (Calcuttan) Street Children Living on and off the Streets Using Drawings." International Journal of Psychology and Psychological Therapy.

Moskal, Marta. 2010. “Visual Methods in Researching Migrant Children's Experiences of Belonging." Migration Letters 7(1):17-31.

Nguyen, Lyma and Christoph Sperfeldt. 2012. Boat Without Anchors: A Report on the Legal Status of Ethnic Vietnamese Minority Populations in Cambodia under Domestic and International Laws Governing Nationality and Statelessness. Jesuit Refugee Service. Phnom Pehn.

O'Kane, C. 2008. “The Development of Participatory Techniques Facilitating Children's Views about Decisions Which Affect Them." in Research with Children: Perspectives 
and Practices, edited by Christensen and James. Florence, KY, USA: Routledge, 2008. Oesterheld, Christian. 2014. “Scapegoating Cambodia's 'Yuon': Historical Perspectives on Khmer Anti-Vietnamism.” Pp. 575-88 in 10th International Academic Conference, Vienna.

Parsons, Laurie and Sabina Lawreniuk. 2018. "Seeing like the Stateless: Documentation and the Mobilities of Liminal Citizenship in Cambodia." Political Geography 62:1-11. Redclift, V. 2013a. "Abjects or Agents? Camps, Contests and the Creation of 'Political Space."” Citizenship Studies 17(3-4):308-21.

Redclift, V. 2013b. Statelessness and Citizenship: Camps and the Creation of Political Space. London, UK: Routledge.

Redclift, Victoria. 2011. "Subjectivity and Citizenship: Intersections of Space, Ethnicity and Identity Among the Urdu-Speaking Minority in Bangladesh.” Journal of International Migration and Integration 12(1):25-42.

Robertson, Shanthi and Elaine Lynn Ee Ho. 2016. “Temporalities, Materialities and Connecting Locales: Migration and Mobility in Asia-Pacific Cities.” Journal of Ethnic and Migration Studies 42(14):2263-71.

Rumsby, C. 2015. Acts of Citizenship and Alternative Perspectives on Voice among Stateless Vietnamese Children in Cambodia. Statelessness Working Paper Series No. 2015/4. Rumsby, C. 2017. "Researching Childhood Statelessness." in The World's Stateless Children, edited by L. van Waas and A. de Chickera. Wolf Legal Publishers.

Rumsby, C. 2019. "Modes of Identity and Belonging among Noncitizen Vietnamese Children Living in Cambodia." Coventry University.

Rydstrøm, H. 2003. Embodying Morality: Growing up in Rural Northern Vietnam. Honolulu: University of Hawai'i Press.

Sapkota, P. and J. Sharma. 1996. "Participatory Interactions with Street Children in Nepal." 
PLA Notes, Special Issue on Children's Participation 25(London: IIED.).

Schliesinger, J. 2015. Ethnic Groups of Laos Vol 2: Profile of Austro-Asiatic-Speaking Peoples.

Sigona, N. 2016. "Everyday Statelessness in Italy: Status, Rights, and Camps.” Ethnic and Racial Studies 39(2):263-279.

Sperfeldt, C. 2017. Report on Citizenship Law: Cambodia. 2017/02.

Tuong, Lai. 1991. "Introduction.” in In Sociological Studies on the Vietnamese Family, edited by R. Liljeström and L. Tuong. Hanoi: Social Sciences Publishing House.

Waterson, Roxana and Deepak Kumar Behera. 2011. "Introduction: Extending Ethnographic Research with Children in the Asia-Pacific Region.” The Asia Pacific Journal of Anthropology 12(5):411-25.

Williams, R. 1977. Marxism and Literature. Oxford: Oxford University Press.

Woods, Orlando. 2012. "The Geographies of Religious Conversion.” Progress in Human Geography 36(4):440-456.

World Bank. 2015. World Development Report 2015. Mind, Society, and Behavior. Washington.

Yang, Fenggang. 1999. "ABC and XYZ: Religious, Ethnic and Racial Identities of the New Second Generation Chinese in Christian Churches." Amerasia Journal 25(1):89-115. Zipin, Lew, Sam Sellar, Marie Brennan, and Trevor Gale. 2015. "Educating for Futures in Marginalized Regions: A Sociological Framework for Rethinking and Researching Aspirations." Educational Philosophy and Theory 47(3):227-46. 